\title{
OVERVIEW OF RAPTOR MONITORING ACTIVITIES IN EUROPE
}

\section{Pregled monitoringa ptic roparic v Evropi}

\author{
Al Vrezec ${ }^{1}$, Guy Duke², András Kovács ${ }^{3}$, Pertti Saurola ${ }^{4}$, Chris Wernham ${ }^{5}$, Ian Burfield ${ }^{6}$, Paola \\ Movalli $^{7} \&$ Irena Bertoncelj ${ }^{1}$ \\ ${ }^{1}$ National Institute of Biology, Večna pot 111, SI-1000 Ljubljana, Slovenia, e-mail: al.vrezec@nib.si, \\ irenabertonceljnib@gmail.com \\ ${ }^{2}$ Oxford University Centre for the Environment, South Parks Road, Oxford, OX1 3QY, United Kingdom, \\ e-mail: guy.duke@skynet.be \\ ${ }^{3}$ Koszorú u. 46, H-3300 Eger, Hungary, e-mail: andras.kovacs.ecol@gmail.com \\ ${ }^{4}$ Finnish Museum of Natural History, P.O. Box 17, FI-00014 University of Helsinki, Finland, \\ e-mail: saurola@cc.helsinki.fi \\ ${ }^{5}$ British Trust for Ornithology (Scotland), School of Natural Sciences, University of Stirling, Stirling, FK9 4LA, \\ Scotland, e-mail: chris.wernham@bto.org \\ ${ }^{6}$ BirdLife International, Wellbrook Court, Girton Road, Cambridge CB3 0NA, United Kingdom, \\ e-mail: ian.burfield@birdlife.org \\ ${ }^{7}$ Institute for Environmental Studies (IVM), VU University, De Boelelaan 1087, 1081 HV Amsterdam, \\ The Netherlands, e-mail: paola.movalli@skynet.be
}

Despite the key role of raptors (including birds of prey Falconiformes and owls Strigiformes) in ecosystems and their sensitivity to environmental change, a well coordinated, Europe-wide monitoring of raptors is lacking. EURAPMON, a Research Networking Programme of the European Science Foundation, was launched with the aim of establishing a sustainable Europewide network for monitoring of raptors. An overview of current monitoring schemes for raptor populations in 28 European countries, as reported by EURAPMON National Coordinators at the workshop in Murcia (Spain) in 2012, showed existing monitoring schemes to be limited to a restricted number of species (mostly diurnal and rare raptor species). The most widely monitored species are the Golden Eagle Aquila chrysaetos amongst diurnal raptors and the Eagle Owl Bubo bubo amongst owls. Broad coverage of a species range across Europe is reached only for restricted-range species. The key driver for monitoring, which is mostly coordinated by NGOs, is conservation, and the main end users are governmental institutions. International collaboration in the field of monitoring of raptors is mainly regional and not yet pan-European in scale. The involvement of volunteers in raptor monitoring was perceived as the main strength of many schemes, but insufficient manpower and a focus on rare species were recognised as the main weaknesses across Europe as a whole. Among priorities identified for the future development of monitoring schemes are: improvements to national coordination; support to increase the number of volunteers; and assurances of stable funding. Further analysis of EURAPMON questionnaires will identify knowledge gaps, which will steer good practice guidance on survey methodologies; the need for the latter was identified as the main benefit that National Coordinators expect to gain from international networking.

Key words: Europe, raptor monitoring scheme, birds of prey, owls, monitoring inventory

Ključne besede: Evropa, monitoring ujed in sov, pregled shem monitoringa 
A. Vrezec, G. Duke, A. Kovács, P. Saurola, C. Wernham, I. Burfield, P. Movalli \& I. Bertoncelj: Overview of raptor monitoring activities in Europe

\section{Introduction}

As top predators, raptors are key species in ecosystems, for which large positive relationships with overall biodiversity have been shown (SERGio et al. 2005). However, the benefits for conservation science of focussing on raptors can be two-fold (Movalli et al. 2008). First, as top predators they are vulnerable to ecosystem degradation and can respond rapidly to biodiversity loss lower down the food chain (Kovács et al. 2008). Second, due to contaminant biomagnification processes, they can act as valuable sentinels of environmental pollution (Helander et al. 2008). Both perspectives are crucial in assessment of the state of ecosystems, since biodiversity loss and contamination have significant environmental, social and economic impacts. Indeed, raptor monitoring can provide relevant information to inform assessment of the effectiveness of EU environmental policy and law aimed at nature conservation and at the prevention of environmental contamination (Duke 2008). Despite this, due to the need for specific survey protocols, raptors are usually poorly covered by more generic common bird censuses (HARDEY et al. 2009). Monitoring schemes for raptors are not spread uniformly across Europe, apply diverse methods, and are conducted at quite different scales, from intensive academic research projects to broad-scale volunteer surveys (Kovács et al. 2008). There is a need to reinforce national and sub-national initiatives and improve coordination of raptor monitoring at pan-European scale. This applies both to monitoring largely focused on the health of raptor populations themselves (which we subsequently refer to as "monitoring for raptors") and to monitoring largely focused on what raptors can tell us about the environment ("monitoring with raptors"). These issues prompted the initiation of EURAPMON, a recently established Research Networking Programme of the European Science Foundation.

Traditionally, only birds of prey (order Falconiformes) were considered as raptors following Hartert's (I9I2) taxonomic division of order Accipitres. However, following modern discussions over the role of raptorial birds as top predators in ecosystems, and due to their similar predatory habits, owls (order Strigiformes) are often also considered as raptors (e.g. Burfield 2008, SAurola 2008). Thus, birds of prey and owls belong to the same ecological guild, i.e. a group of ecologically similar species exploiting the same environmental resources in a similar way as defined by Rоот (1967), within which strong competitive and even intraguild predation interactions are described (CAROTHERES \& JAKSIC i984, Sergio et al. 2003, Vrezec \& Tome 2004, Sergio \& Hiraldo 2008). Some recent views on raptor assemblages define raptors even more broadly, including some passerine groups: shrikes (Laniidae), as indicated by publications in the Journal of Raptor Research; and even some corvids (Corvidae), i.e. Raven Corvus corax (HaRdey et al. 2009). In this sense, ecologically based views are actually repeating old taxonomic considerations of raptors as the former order Accipitres, comprising birds of prey, owls and shrikes (Linnaeus 1758). For the purposes of the EURAPMON programme and this paper, however, only top predator species with an apex role in ecosystems are included, which require specific methodological approaches for monitoring: birds of prey (Falconiformes; diurnal raptors) and owls (Strigiformes; mainly nocturnal raptors).

The EURAPMON inventory of raptor population monitoring (monitoring for raptors) in Europe was initiated in 2012. The inventory will form the basis of future development of common monitoring approaches, including good practice guidance on survey methodologies and analysis of data. It will assist in setting priorities and is complementary to, and will be used in conjunction with, a similar inventory of with raptor monitoring schemes across Europe (Gómez-Ramírez et al. submitted) to foster cross-cooperation between these two monitoring communities. A network of National Coordinators has been established for the monitoring for raptors, who have the combined role of facilitating data provision for the inventory and promoting common pan-European raptor monitoring activities.

The for raptors monitoring inventory was launched at a workshop held in Murcia, Spain, 7-10 February 2012, organized by EURAPMON to bring together the National Coordinators for the first time to report on the monitoring schemes existing in their countries (EURAPMON 20I3). This paper aims to provide an overview of the main insights arising from the National Coordinators' reports, providing a first up to date review of current monitoring activities for raptors across Europe. A further paper will synthesize the results of a subsequent questionnaire survey of those carrying out raptor monitoring across Europe and provide more detail on the particular biological parameters that are monitored, variation in survey methods across Europe and individual species coverage.

\section{Material and methods}

At the workshop held in Murcia in 2012, the appointed National Coordinators each provided a PowerPoint 
presentation reviewing the current status of monitoring for raptors within their country (available at http://www.eurapmon.net), following this with papers summarising the current state of knowledge (published within this issue of Acrocephalus). The workshop participants were asked to answer a set of standard questions under five topics, covering a range of relevant monitoring issues:

(1) Main players

- Who are the main actors in monitoring for raptors in your country?

- Which are the main countries with which you collaborate, within your region, within Europe and/or globally?

- Who are the main users of the data obtained from this monitoring and for what purpose do they use the data?

(2) National coverage

- Is there any national co-ordination? By whom?

- Is there a national network for monitoring for raptors?

- How comprehensive or patchy, spatially, is monitoring across the country?

(3) Key species and key issues

- What are the key species addressed by monitoring for raptors in your country?

- What are the key issues (threats) addressed by monitoring for raptors in your country?

- For which, if any, of these species and issues might your country most benefit from international networking?

(4) Strengths and weaknesses

- What are the main strengths and weaknesses of monitoring for raptors in your country?

- What are the main gaps (species, regions, threats...) in monitoring for raptors in your country?

- Are there specific areas of weakness, or challenges, for which your country might benefit from international sharing of good/best practice?

(5) Priorities, capacity-building

- What are the priorities to strengthen monitoring for raptors in your country?

- What are the main capacity-building needs to strengthen for monitoring for raptors in your country?

The responses have been summarized and pooled into groups containing related answers. Some questions were not answered for all countries, so in the analysis we have excluded those countries in which National Coordinators have skipped certain questions. The scale of international collaboration was measured as distances between capital cities of collaborating countries. The scale was estimated by comparing actual collaboration distances with all possible distances between capital cities in Europe, assuming that the latter would reflect a pan-European collaboration scale. Non-parametric and $\chi^{2}$ statistical tests have been used whenever needed for numerical evaluation of the data. The known presence of breeding raptor populations in European countries followed BirdLife InTERnational (2004), and only for poorly known countries have recent updates been taken into account, e.g. Bosnia and Herzegovina (Kotrošan \& Hatibović 2OI2). In the paper we deal especially with monitoring of breeding populations and less with migration and wintering monitoring issues, which were less comprehensively covered with the current survey approach.

\section{Results and discussion}

Within this overview we have collected reports of raptor monitoring activity from 28 European countries (in alphabetical order; see also Figure 2): Austria, Belarus, Belgium, Bosnia \& Herzegovina, Bulgaria, Croatia, Czech Republic, Estonia, Finland, France, Georgia, Germany, Greece, Hungary, Ireland, Italy, Latvia, Malta, Norway, Poland, Portugal, Romania, Russia, Slovakia, Slovenia, Spain, Sweden and United Kingdom. Surveyed countries comprise $58 \%$ of all countries and $83 \%$ of the whole territory of Europe covered by EURAPMON (which includes Europe east to the Urals, Georgia, Armenia, Azerbaijan and Turkey).

\subsection{Main players}

In more than $90 \%$ of surveyed countries, monitoring for raptors is conducted by non-governmental organisations (NGOs), such as ornithological societies, BirdLife Partners and other associations (Figure 1 left). However, in $75 \%$ of countries, governmental (i.e. ministries, environmental agencies, protected areas administrations) and research institutions (i.e. universities, research institutes, museums) are also involved in running monitoring schemes. In some countries, further monitoring activities are the result of the enthusiasm of individuals, and monitoring is conducted only via private initiatives. The latter monitoring schemes are usually small-scale, but not necessarily short-term.

Large-scale, country-wide monitoring schemes usually incur higher costs, such that stable financing is necessary to conduct them in the long-term. For this reason, the needs of users of monitoring data are crucial 
A. Vrezec, G. Duke, A. Kovács, P. Saurola, C. Wernham, I. Burfield, P. Movalli \& I. Bertoncelj: Overview of raptor monitoring activities in Europe

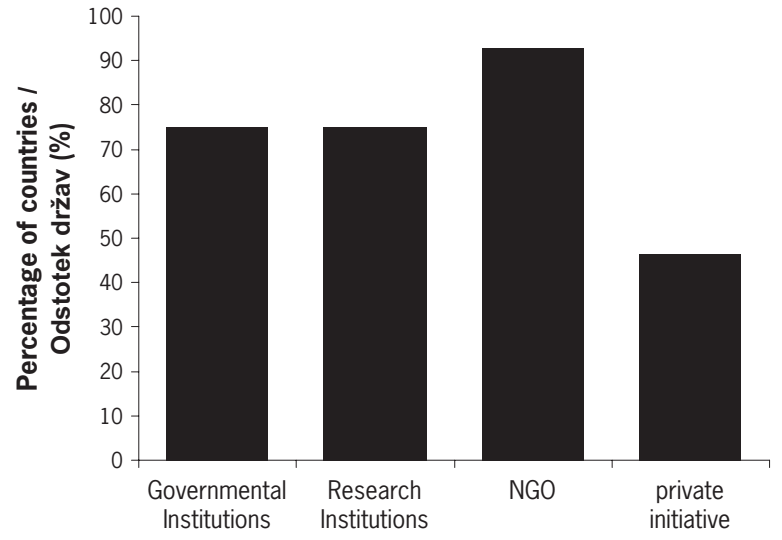

Main actors / Glavni protagonisti

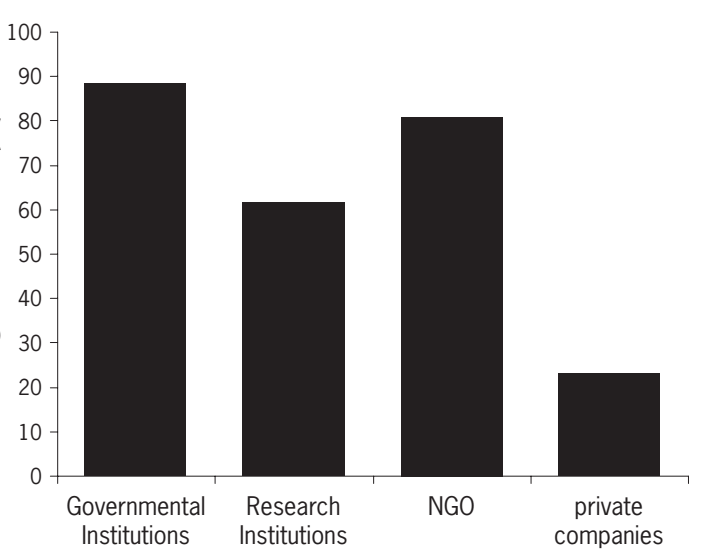

Main users / Glavni uporabniki

Figure 1: Main actors conducting monitoring for raptors in Europe ( $n=28$ countries) and main users of data of monitoring for raptors in Europe by the percentage of the surveyed countries ( $n=26$ countries). Each country can appear more than once in each graph.

Slika 1: Glavni protagonisti monitoringa populacij ptic roparic v Evropi ( $n=28$ držav) in glavni uporabniki podatkov monitoringa populacij ptic roparic v Evropi po odstotkih sodelujočih držav ( $n=26$ držav). Vsaka država je lahko upoštevana več kot enkrat $v$ obeh grafikonih.

to consider when setting up monitoring schemes. In $88 \%$ of the surveyed European countries, the main identified users of monitoring data are governmental institutions (Figure 1 right), particularly for implementing their international monitoring obligations set by, for example, EU Directives (see an overview in Duke 2008). However, National Coordinators also reported large user needs for monitoring data within NGOs, particularly for assessing species' conservation status and other conservation issues (e.g. BURFIELD 2008). Research institutions are in general less involved with the analysis and management of monitoring data (Figure 1 right), and this was reported as one of the main weaknesses of monitoring schemes by many National Coordinators (see later). Due to obligations to assess the environmental and biodiversity impacts of development, many private companies are also involved in monitoring activities as both data users and monitoring funders (e.g. to carry out work to assess the impacts of wind farms, power lines etc.), although such monitoring activities are usually undertaken at a local scale only.

According to information obtained from National Coordinators, there is some existing network of international collaboration for the monitoring for raptors in Europe, with 102 different contacts reported (Figure 2). Our measure of the scale of this network (measured as distances between capital cities) has shown that this network represents more or less regional, but not pan-European, scale collaboration, with the majority of contacts restricted to neighbouring countries (Figure 3). The current network is significantly (Mann-Whitney $U=26,290, P<0.0001$ ) limited to short distance collaboration (median distance 680 $\mathrm{km}, \mathrm{n}=102$ connections) compared to potential overall pan-European collaboration (median distance $1,314 \mathrm{~km}, \mathrm{n}=946$ connections; see Figure 3). Long distance collaborations reported usually involved the monitoring of migrating raptors, with collaboration for monitoring of breeding populations less evident. Aside from EURAPMON, there are few existing collaborative initiatives aimed at moving towards pan-European monitoring for raptors: the MEROS programme and initiatives by BirdLife International and the European Bird Census Council (EBCC) are relevant in this respect (Kovács et al. 2008). Despite this, some countries reported intercontinental collaboration with South America, Africa and Asia, suggesting some global networking already exists for monitoring for raptors. These global connections were not targeted specifically within the current survey, and are thus probably underestimated in our results.

\subsection{National Coverage}

At least some national coordination of monitoring activity exists in $71 \%$ of surveyed countries. Most of the coordination is limited to one or a restricted number of species ( $43 \%$ of surveyed countries), while comprehensive coordination for monitoring 


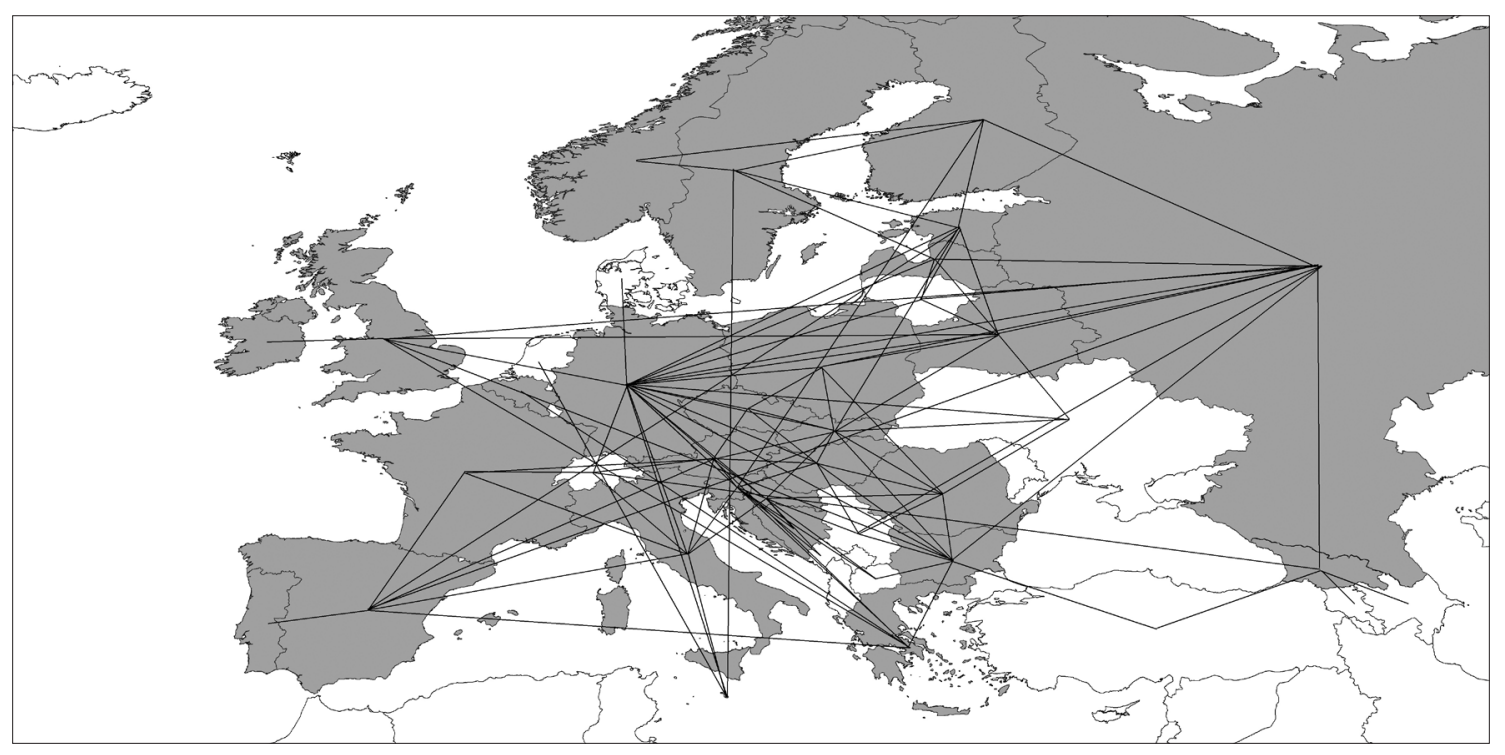

Figure 2: The current international collaboration network in Europe for monitoring for raptors, showing reported collaboration contacts between countries. Countries from which data were obtained are shaded grey.

Slika 2: Trenutno omrežje mednarodnega sodelovanja v Evropi v okviru monitoringa populacij ptic roparic s sporočanimi stiki sodelovanja med državami. Države, od katerih so bili pridobljeni podatki o monitoringu, so obarvane sivo.

of the whole raptor community or of the majority of raptor species within countries is less frequent $(36 \%$ of surveyed countries). National coordination of monitoring schemes for raptors is mainly confined to NGOs ( $85 \%$ of the countries with reported national coordination). Only in a few countries is the national coordination conducted by research or governmental institutions (Figure 4), for example the comprehensive monitoring scheme (national Raptor Grid) in Finland, which is coordinated by the Finnish Museum of Natural History, University of Helsinki (SaURola 2008).

\subsection{Key species}

Monitoring activity exists for 50 (90\%) of the 56 known breeding raptor species in Europe. Among the species monitored in most European countries are the Golden Eagle Aquila chrysaetos, White-tailed Eagle Haliaeetus albicilla and Peregrine Falcon Falco peregrinus (Table 1). Considering species range coverage, the whole European range is monitored for just two species: the Spanish Imperial Eagle $A$. adalberti and Steppe Eagle A. nipalensis, both of which are range-restricted in Europe to one or two countries only (BirdLife InTERnational 2004). The results suggest that for $62 \%$ of diurnal raptors, more than half of the species range is monitored in Europe,

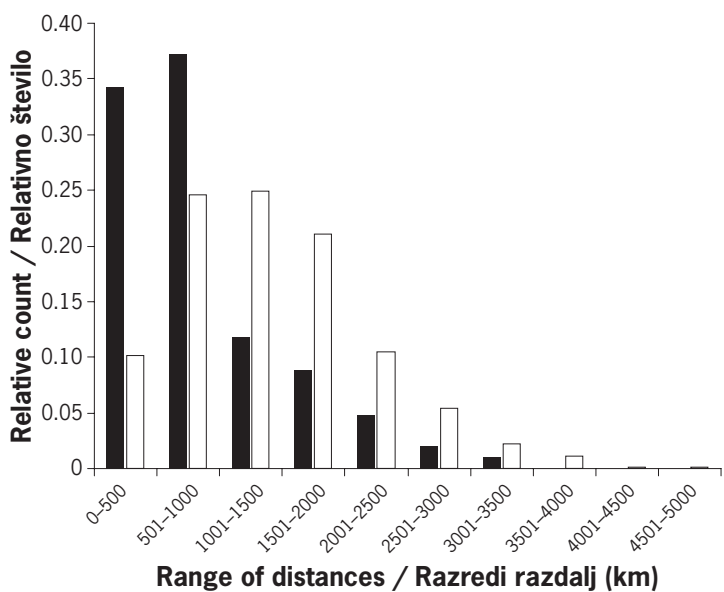

Figure 3: Range of international collaboration between European countries for monitoring for raptors, measured as distances between capital cities of collaborating countries. Dark columns show the actual collaboration detected, and light columns show the potential for collaboration if all possible connections between countries in Europe were made. The relative count is the proportion of the number of distances within actual or potential collaboration.

Slika 3: Razpon mednarodnega sodelovanja med evropskimi državami pri monitoringu populacij ptic roparic, izmerjen z razdaljami med glavnimi mesti sodelujočih držav. Temni stolpci prikazujejo dejansko sodelovanje, svetli stolpci pa potencialno sodelovanje, če se vzpostavijo vsi možni stiki med državami v Evropi. Relativno število je delež števila razdalj znotraj dejanskega ali potencialnega sodelovanja. 
Table 1: Monitoring schemes for bird of prey species (Falconiformes) established in Europe (only species breeding in surveyed European countries are shown; according to BIRDLIFE INTERNATIONAL (2004), KotRoŠAN \& HATIBOvić (2012). The number of countries and estimated percentage of the species range in Europe covered by monitoring schemes as reported in the survey are shown (monitoring coverage of European range is calculated as the percentage of countries with a species population in which monitoring is conducted).

Tabela 1: Sheme monitoringa za ujede (Falconiformes), osnovane v Evropi (prikazane so samo vrste, ki gnezdijo v sodelujočih evropskih državah; po BiRDLIFE InTERnATIONAL (2004), KotRoŠAn \& HatiBović (2012). Tabela prikazuje število držav in ocenjene odstotke arealov vrst v Evropi, ki jih pokrivajo sheme monitoringa, kot je bilo sporočeno v popisih (obseg monitoringa v evropskem arealu je izračunan kot odstotek držav s populacijami vrst, v katerih je bil opravljen ali poteka monitoring).

\begin{tabular}{|c|c|c|}
\hline Species / Vrsta & No. of countries / Št. držav & $\begin{array}{l}\text { Monitoring coverage of European range / } \\
\text { Obseg monitoringa v evropskem arealu (\%) }\end{array}$ \\
\hline Golden Eagle Aquila chrysaetos & I8 & 75 \\
\hline White-tailed Eagle Haliaeetus albicilla & I7 & $8 \mathrm{I}$ \\
\hline Peregrine Falcon Falco peregrinus & I7 & 68 \\
\hline Montagu's Harrier Circus pygargus & I2 & 50 \\
\hline Kestrel Falco tinnunculus & I2 & 43 \\
\hline Osprey Pandion haliaetus & I I & 85 \\
\hline Red Kite Milvus milvus & II & 6I \\
\hline Marsh Harrier Circus aeruginosus & IO & 40 \\
\hline Goshawk Accipiter gentilis & IO & 37 \\
\hline Buzzard Buteo buteo & IO & 37 \\
\hline Lesser Spotted Eagle Aquila pomarina & 9 & 56 \\
\hline Saker Falcon Falco cherrug & 8 & 73 \\
\hline Black Kite Milvus migrans & 8 & 35 \\
\hline Honey Buzzard Pernis apivorus & 8 & $3 \mathrm{I}$ \\
\hline Sparrowhawk Accipiter nisus & 8 & 30 \\
\hline Egyptian Vulture Neophron percnopterus & 7 & 87 \\
\hline Imperial Eagle Aquila heliaca & 7 & 70 \\
\hline Red-footed Falcon Falco vespertinus & 7 & 54 \\
\hline Hobby Falco subbuteo & 7 & 27 \\
\hline Griffon Vulture Gyps fulvus & 6 & 67 \\
\hline Lesser Kestrel Falco naumanni & 6 & 54 \\
\hline Northern Harrier Circus cyaneus & 6 & 33 \\
\hline Lammergeier Gypaetus barbatus & 5 & 83 \\
\hline Greater Spotted Eagle Aquila clanga & 5 & $7 \mathrm{I}$ \\
\hline Black Vulture Aegypius monachus & 4 & 57 \\
\hline Bonelli's Eagle Aquila fasciata & 4 & 57 \\
\hline Merlin Falco columbarius & 4 & 50 \\
\hline Short-toed Eagle Circaetus gallicus & 4 & 22 \\
\hline Eleonora's Falcon Falco eleonorae & 3 & 75 \\
\hline Gyrfalcon Falco rusticolus & 3 & 75 \\
\hline Spanish Imperial Eagle Aquila adalberti & 2 & IOO \\
\hline Rough-legged Buzzard Buteo lagopus & 2 & 50 \\
\hline Lanner Falcon Falco biarmicus & 2 & 33 \\
\hline Booted Eagle Aquila pennata & 2 & I3 \\
\hline Steppe Eagle Aquila nipalensis & I & IOO \\
\hline Black-winged Kite Elanus caeruleus & I & 33 \\
\hline Long-legged Buzzard Buteo rufinus & I & I4 \\
\hline Pallid Harrier Circus macrourus & o & o \\
\hline Levant Sparrowhawk Accipiter brevipes & o & o \\
\hline
\end{tabular}


particularly for threatened species. Species with lower monitoring coverage in Europe are mainly common and widespread species (e.g. Buzzard Buteo buteo, Honey Buzzard Pernis apivorus, Goshawk Accipiter gentilis, Sparrowhawk A. nisus) and species breeding predominantly in southern and eastern Europe (e.g. Long-legged Buzzard B. rufinus, Booted Eagle $A$. pennata, Short-toed Eagle Circaetus gallicus). However, from annually operated breeding bird surveys in 21 European countries, PECBMS (2009) was able to produce population trends at least for some common raptors at the pan-European scale, i.e. Sparrowhawk, Buzzard, Marsh Harrier Circus aeruginosus, and Kestrel F. tinnunculus. Two species breeding in surveyed countries, Pallid Harrier C. macrourus and Levant Sparrowhawk $A$. brevipes, are not covered by any reported monitoring scheme.

Less comprehensive monitoring of owl populations in Europe is suggested by the lower number of countries conducting owl monitoring as well as by the lower monitoring coverage of European ranges compared to diurnal raptors (median coverage of owls per species is $37 \%$, median coverage of birds of prey per species is $54 \%$; Tables $1 \& 2$ ). The most monitored owl species in Europe is the Eagle Owl Bubo bubo, but the highest monitoring coverage of breeding population in Europe is for the Great Grey Owl Strix nebulosa, which has a range restricted to only five

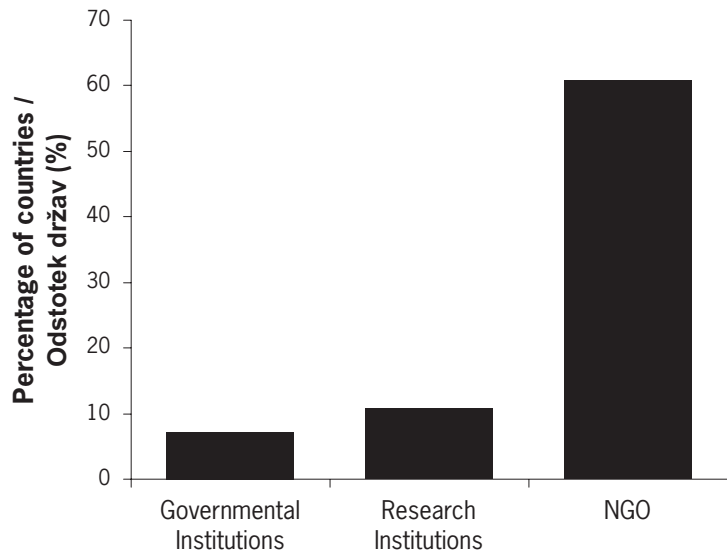

Organisations / Organizacije

Figure 4: Organisations involved in national coordination of monitoring activities for raptors in surveyed European countries $(n=20)$

Slika 4: Organizacije, vključene v nacionalno koordinacijo monitoringa populacij ptic roparic $v$ sodelujočih evropskih državah $(n=20)$

European countries (BirdLife InTERnATIONAL 2004) and is monitored at least in four of these. Only for $23 \%$ of owl species is more than half of the species range reported as monitored in Europe, and other

Table 2: Owls (Strigiformes) for which monitoring schemes are established in Europe. The number of countries and estimated percentage of the species range in Europe covered by monitoring schemes are shown (monitoring coverage of the European range is calculated as the percentage of countries with a species population in which monitoring is conducted).

Tabela 2: Sove (Strigiformes) z obstoječimi shemami monitoringa v Evropi. Tabela prikazuje število držav in ocenjene odstotke arealov vrst v Evropi, ki jih pokrivajo sheme monitoringa (obseg monitoringa v evropskem arealu je izračunan kot odstotek držav s populacijami vrst, v katerih je bil opravljen ali poteka monitoring).

\begin{tabular}{lcc}
\hline Species / Vrsta & No. of countries / Št. držav & $\begin{array}{c}\text { Monitoring coverage of European range / } \\
\text { Obseg monitoringa v evropskem arealu (\%) }\end{array}$ \\
\hline Eagle Owl Bubo bubo & I5 & 58 \\
Tawny Owl Strix aluco & Io & 40 \\
Tengmalm's Owl Aegolius funereus & 9 & 37 \\
Long-eared Owl Asio otus & 9 & 33 \\
Ural Owl Strix uralensis & 8 & 42 \\
Barn Owl Tyto alba & 7 & 29 \\
Pygmy Owl Glaucidium passerinum & 6 & 32 \\
Little Owl Athene noctua & 5 & 23 \\
Short-eared Owl Asio flammeus & 5 & 22 \\
Great Grey Owl Strix nebulosa & 4 & 80 \\
Snowy Owl Bubo scandiacus & 2 & 50 \\
Hawk Owl Surnia ulula & 2 & 40 \\
Scops Owl Otus scops & 2 & $\mathrm{I}$ \\
\hline
\end{tabular}


A. Vrezec, G. Duke, A. Kovács, P. Saurola, C. Wernham, I. Burfield, P. Movalli \& I. Bertoncelj: Overview of raptor monitoring activities in Europe

Table 3: Preliminary overview of monitoring of raptor non-breeding populations in Europe, showing the number of surveyed countries which reported migration and/or wintering monitoring

Tabela 3: Predhodni pregled monitoringa populacij negnezdečih ptic roparic v Evropi s številom sodelujočih držav, ki so poročale o monitoringu selečih se in/ali prezimujočih vrst

\begin{tabular}{|c|c|c|}
\hline Species / Vrsta & Monitoring & No. of countries / Št. držav \\
\hline Honey Buzzard Pernis apivorus & Migration & 5 \\
\hline Black Kite Milvus migrans & Migration & 4 \\
\hline Marsh Harrier Circus aeruginosus & Migration & 4 \\
\hline Short-toed Eagle Circaetus gallicus & Migration & 3 \\
\hline Osprey Pandion haliaetus & Migration & 3 \\
\hline Kestrel Falco tinnunculus & Migration & 3 \\
\hline Red-footed Falcon Falco vespertinus & Migration & 3 \\
\hline Griffon Vulture Gyps fulvus & Migration & 2 \\
\hline Black Vulture Aegypius monachus & Migration & 2 \\
\hline Pallid Harrier Circus macrourus & Migration & 2 \\
\hline Montagu's Harrier Circus pygargus & Migration & 2 \\
\hline Goshawk Accipiter gentilis & Migration & 2 \\
\hline Buzzard Buteo buteo & Migration & 2 \\
\hline Long-legged Buzzard Buteo rufinus & Migration & 2 \\
\hline Lesser Kestrel Falco naumanni & Migration & 2 \\
\hline Hobby Falco subbuteo & Migration & 2 \\
\hline White-tailed Eagle Haliaeetus albicilla & Migration & I \\
\hline Lammergeier Gypaetus barbatus & Migration & I \\
\hline Egyptian Vulture Neophron percnopterus & Migration & I \\
\hline Hen Harrier Circus cyaneus & Migration & I \\
\hline Sparrowhawk Accipiter nisus & Migration & I \\
\hline Levant Sparrowhawk Accipiter brevipes & Migration & I \\
\hline Rough-legged Buzzard Buteo lagopus & Migration & I \\
\hline Lesser Spotted Eagle Aquila pomarina & Migration & I \\
\hline Greater Spotted Eagle Aquila clanga & Migration & I \\
\hline Steppe Eagle Aquila nipalensis & Migration & I \\
\hline Imperial Eagle Aquila heliaca & Migration & I \\
\hline Golden Eagle Aquila chrysaetos & Migration & I \\
\hline Booted Eagle Aquila pennata & Migration & I \\
\hline Merlin Falco columbarius & Migration & I \\
\hline Eleonora's Falcon Falco eleonorae & Migration & I \\
\hline Saker Falcon Falco cherrug & Migration & I \\
\hline Peregrine Falcon Falco peregrinus & Migration & I \\
\hline Long-eared Owl Asio otus & Wintering & 4 \\
\hline Black Kite Milvus migrans & Wintering & 2 \\
\hline Montagu's Harrier Circus pygargus & Wintering & 2 \\
\hline Red Kite Milvus milvus & Wintering & I \\
\hline White-tailed Eagle Haliaeetus albicilla & Wintering & I \\
\hline Hen Harrier Circus cyaneus & Wintering & I \\
\hline
\end{tabular}

species are monitored to a rather limited extent. The least monitored are Scops Otus scops and Short-eared Owl Asio flammeus, which are the only truly migratory owl species in Europe (Mikкola I983).

Monitoring of non-breeding populations, i.e. monitoring of migration and wintering populations, was less well covered by the current survey. As expected, the most monitored species within migration monitoring schemes is the Honey Buzzard (Table 3), since this species is probably the most 


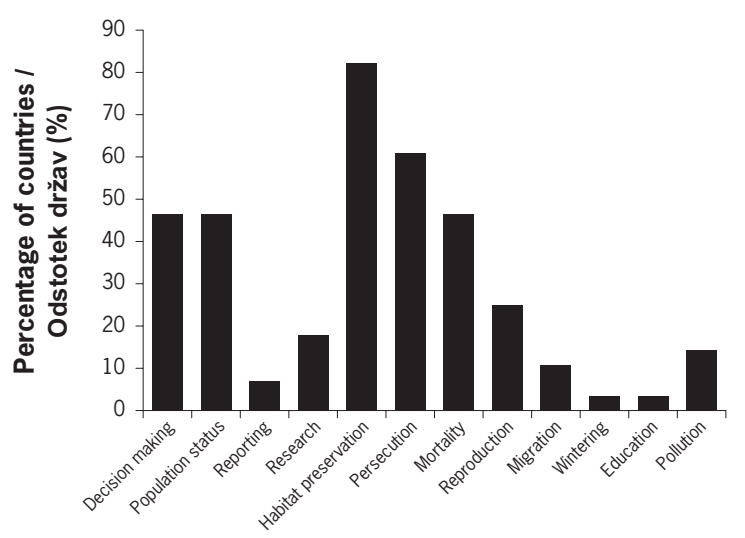

Key issues / Ključni cilji

Figure 5: Frequency of key issues of raptor monitoring in Europe as reported by surveyed countries $(n=28)$

Slika 5: Pogostost ključnih ciljev pri monitoringu ptic roparic $v$ sodelujočih evropskih državah $(n=28)$

numerous and widespread migrating raptor confined to bottlenecks during migration. The only owl species covered by non-breeding population monitoring is the Long-eared Owl A. otus, for which systematic counting at winter roosting sites is becoming more widespread in some European countries (e.g. Ružić et al. 2010).

\subsection{Key issues}

We have identified 12 key issues that have been addressed by National Coordinators for raptor monitoring schemes in Europe: (1) decision making (conservation and agricultural policy, Natura 2000 site monitoring, Red List/Red Data Book preparation, management plans), (2) defining species population status (including faunistic and atlas projects), (3) reporting (to local, national or EU authorities), (4) research, (5) habitat preservation (monitoring of threats and habitat loss), (6) persecution (hunting, illegal trade, poisoning), (7) mortality (electrocution, wind farms and other sources of increased mortality in raptors), (8) reproduction (monitoring breeding success), (9) migration, (10) wintering populations, (11) education (publicity and public relations), and (12) pollution (connected to with raptor monitoring issues). In the majority of raptor monitoring schemes, issues connected to conservation predominate, e.g. habitat preservation, persecution, mortality, population status, but also decision making policy (Figure 5). These issues are not surprising, since most of the users of monitoring data are governmental institutions and
NGOs (Figure 1 right). In current monitoring schemes for raptors, issues related to research and monitoring with raptors (notably, contaminant monitoring) are rarely addressed. Enhancing contaminant monitoring in raptors could serve to draw greater attention to the value of monitoring raptors.

The National Coordinators were asked about the benefits that could accrue to them from international networking. Based on their responses, we have defined 10 main groups of such benefits: (1) international associations (e.g. BirdLife International, EBCC or raptor specific associations), (2) projects and funding, (3) manpower (to support monitoring schemes of international importance with volunteers from abroad), (4) conservation issues (international approach to solving main conservation problems, e.g. creating international pressure on local authorities), (5) threatened species (common approaches and knowledge exchange about monitoring and conservation of target species, e.g. Imperial Eagle, White-tailed Eagle, Saker Falcon $F$. cherrug, Gyrfalcon F. rusticolus), (6) common trends (comparison of population trends), (7) research, (8) sharing best practice (common monitoring protocols, standardisation of methods, monitoring of threats), (9) migration (bottleneck counts, telemetry studies), and (10) pollution (connected to with raptor monitoring). Best practice and funding were the two most frequently cited benefits of European networking (Figure 6).

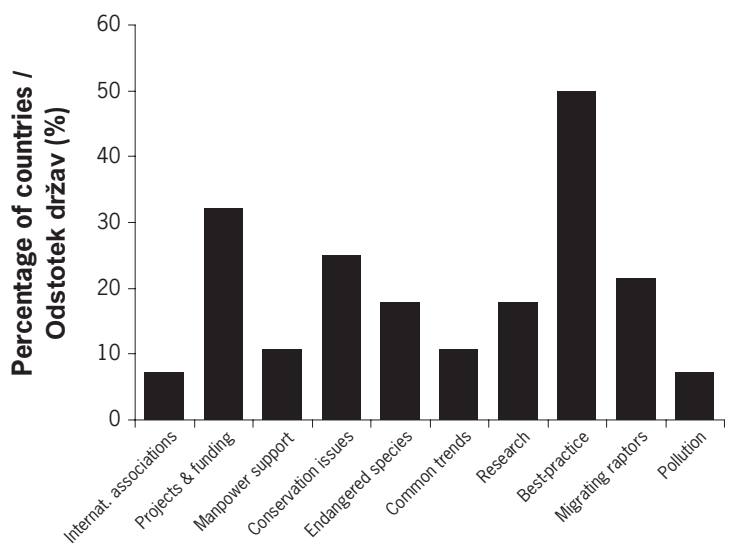

Main benefits / Glavne koristi

Figure 6: Frequency of main benefits of international networking in raptor monitoring in Europe as identified by surveyed countries $(n=28)$

Slika 6: Pogostost glavnih koristi mednarodnega povezovanja pri monitoringu ptic roparic v Evropi, kot so bile ugotovljene v sodelujočih državah $(n=28)$ 
A. Vrezec, G. Duke, A. Kovács, P. Saurola, C. Wernham, I. Burfield, P. Movalli \& I. Bertoncelj: Overview of raptor monitoring activities in Europe

\subsection{Strengths and weaknesses of existing monitoring schemes}

The reported strengths of existing monitoring schemes for raptors in Europe can be divided into 12 thematic groups: (1) long-term monitoring scheme (several schemes in Europe cover 20 or more years of annual counts), (2) endangered species (several monitoring schemes focus on rare and endangered species or species of conservation importance, e.g. qualifying species at Natura 2000 sites), (3) migration monitoring (some countries have well developed monitoring of migrating but not breeding raptors), (4) research (especially where research institutions are more involved in data collection, monitoring coordination or as data users), (5) conservation (where monitoring is contributing more to the conservation of the species alongside other concurrent conservation activities), (6) volunteers (availability and organisation of volunteers supporting monitoring activities is sufficient in some countries), (7) network (good organized network for raptor enthusiasts enabling also enough volunteers to get involved in monitoring activities), (8) good coverage (covering national range of monitored species or in the country more or less all occurring raptor species are monitored), (9) database (organised monitoring database at national scale), (10) monitoring protocols (developed and available monitoring protocols used by all professional and voluntary fieldworkers involved in programmes), (11) public interest (connected also to funding available for monitoring), and (12) funding (crucial for comprehensive and long-term monitoring scheme development). Two strengths of monitoring for raptors schemes were most frequently cited as important, volunteers and research (Figure 7 left).

The most frequently cited weakness/gap relates to missing coverage for certain species, common species and/or owls (Figure 7 right). We have identified in total 14 weaknesses/gaps based on the responses of National Coordinator (Figure 7 right): (1) no national coordination, (2) no data sharing (different monitoring schemes in the country are not connected and apparently the willingness to share existing data is low), (3) low funding (one of the main weaknesses, which prevents development of more comprehensive monitoring schemes), (4) only short-term and local schemes, (5) no conservation monitoring (usually only population monitoring is conducted, but no threats are monitored), (6) low research and data publishing (the reason addressed is general lack of interest in monitoring data by research institutions, while interest for data publishing by NGOs, which conduct most of the schemes, is usually low), (7) lack of volunteers, (8) fieldwork problems (in some countries fieldwork conditions can prevent more comprehensive monitoring scheme development, e.g. intensive hunting or mine fields), (9) no protocols (or no best practice, which is the major issue highlighted already as a major benefit of an international network), (10) missing species (especially common raptors and owls), (11) no monitoring of breeding success (more time consuming monitoring than pure counts of territories or individuals is not conducted

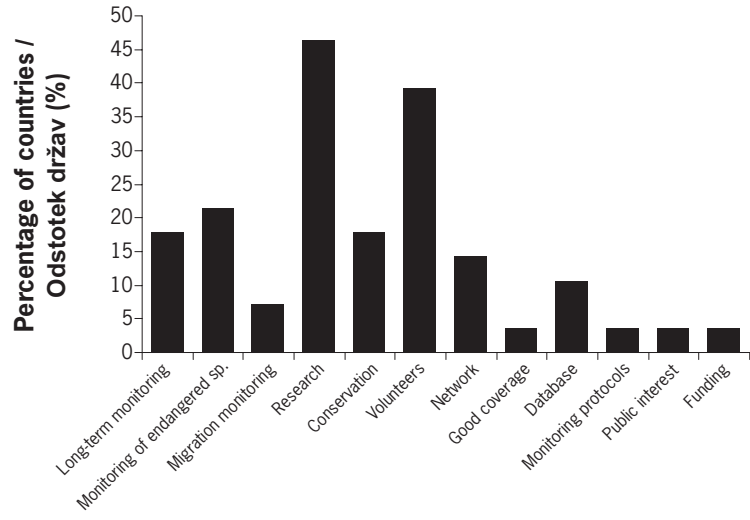

Strengths / Prednosti

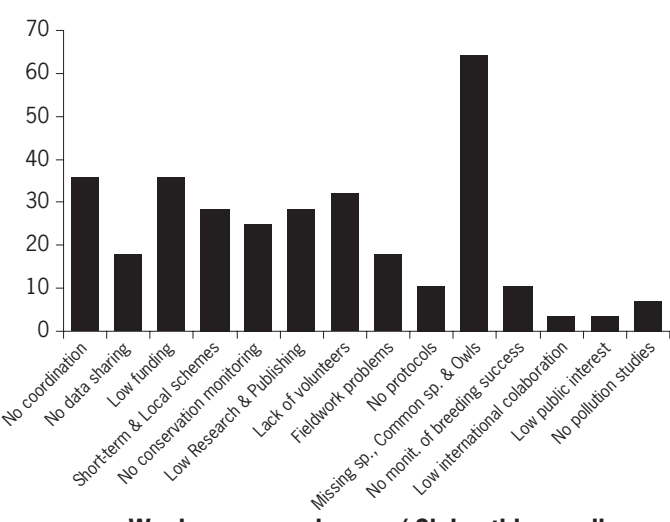

Weaknesses and gaps / Slabosti in vrzeli

Figure 7: Frequency of the strengths (left graph) and weaknesses and gaps (right graph) of existing raptor monitoring schemes in Europe as suggested by surveyed countries $(n=28)$

Slika 7: Pogostost prednosti (levi grafikon) ter slabosti in vrzeli (desni grafikon) v obstoječih shemah monitoringa ptic roparic $\checkmark$ Evropi glede na poročila sodelujočih držav $(n=28)$ 


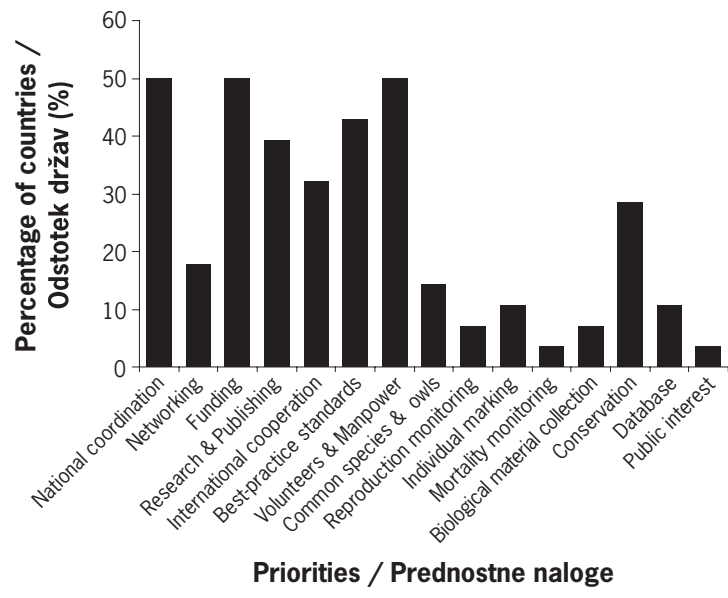

Figure 8: Overview of priorities and capacity building needs for monitoring for raptors as suggested by surveyed European countries $(n=28)$

Slika 8: Pregled prednostnih nalog in potreb po povečanju kapacitet za monitoring populacij ptic roparic, kot jih sporočajo iz sodelujočih evropskih držav $(n=28)$

due to limited financial or manpower sources), (12) low international collaboration (collaboration usually involves neighbouring countries having some common monitoring interest), (13) low public interest (apparent in many countries but not a main weakness), and (14) no monitoring with raptors scheme (usually involving a lack of trained experts or adequate laboratories).

\subsection{Priorities and capacity building needs}

Priorities and capacity building needs were addressed by separate questions but the responses by National Coordinators to these two questions were somewhat similar. For example, around half of respondents cited an increase in the number of volunteers as both a priority and a capacity-building need (Figure 8). Cited priorities and capacity-building needs included: (1) increasing volunteers and manpower for monitoring activities, (2) the development of national coordination and national schemes, (3) funding for long-term and comprehensive monitoring schemes, (4) best-practice standards development, possibly on an international level, (5) international collaboration, (6) enhancing research monitoring activities with possibly annual publishing of monitoring results, (7) increased attention to conservation issues (i.e. conservation strategy development and monitoring of main threats), (8) networking, (9) development of more comprehensive monitoring scheme by including common raptors and owls, (10) starting reproduction monitoring, (11) individual marking (i.e. raptor ringing and telemetry), (12) mortality monitoring, (13) collecting biological material (e.g. egg shells, feathers, carcasses) for monitoring with raptors purposes (14) national database development, and (15) increase in public awareness about raptors, their threats and population trends.

However, in general among the main priorities for future development of monitoring schemes, only a few countries actually suggested development of more comprehensive monitoring schemes through the inclusion of common raptors and owls (compare Figures 7 right and 8). Hence current priorities identified by individual countries appear to omit the most frequently suggested weakness of current schemes, a gap that a pan-European raptor monitoring network like EURAPMON should prioritize and facilitate inclusion of common diurnal raptors and owls into existing monitoring in Europe wherever possible.

\section{Conclusions}

This preliminary overview of for raptor monitoring in Europe gives a useful insight into the level of current monitoring activities, perceived gaps and needs identified by each country. This study will be followed up by a more comprehensive inventory using a systematic approach (based on a detailed questionnaire), which was launched on the EURAPMON website at the end of 2012, actively publicised by the EURAPMON network of National Coordinators, and aims to cover all European countries (to the Urals), including those on the far eastern border of Europe.

In summary, our current knowledge of existing monitoring for raptors in Europe from this study shows that:

- the main players conducting and coordinating raptor monitoring activities in Europe are NGOs, while the main end users and funders are governmental institutions;

- international collaboration for raptor monitoring in Europe is mainly regional (and largely nearestneighbour driven) and not yet pan-European in extent;

- most monitoring schemes are confined to small numbers of species, usually species of conservation importance, and do not cover the whole raptor community within the country;

- the most widely monitored species are the Golden Eagle amongst diurnal raptors and the Eagle Owl 
A. Vrezec, G. Duke, A. Kovács, P. Saurola, C. Wernham, I. Burfield, P. Movalli \& I. Bertoncelj: Overview of raptor monitoring activities in Europe

amongst owls, and in general good range coverage is reached only for restricted-range species;

- conservation is reported as the key driver for raptor monitoring schemes in Europe;

- the development and sharing of best-practice is the most beneficial aspect expected by National Coordinators from an international network;

- the greatest strengths of monitoring schemes for raptors in Europe are volunteers, which are in some countries still lacking, preventing those countries from conducting more comprehensive monitoring schemes;

- the main gaps in many European raptor monitoring schemes are the lack of coverage of commoner diurnal raptor and owl species;

- priorities reported for future development of national monitoring schemes for raptors in Europe are: improvements to national coordination, support to increase the number of volunteers available to participate and assurances of stable funding;

- current priorities identified by individual National Coordinators rarely include one of the main weakness identified in current monitoring schemes, specifically the lack of inclusion of common diurnal raptors and owls, and this should be one of the developments that a future pan-European network in the field of monitoring for raptors can facilitate.

Acknowledgements: The study was conducted with the support of the European Science Foundation (ESF) in the scope of the Research Networking Programme EURAPMON. Data on monitoring activities for raptors was collected at the workshop held in February 2012 in Murcia (Spain). The workshop was hosted by CEMACAM and funded by EURAPMON (ESF) and the Spanish Ministry of Research and Innovation. We would like to thank the local organisers of the workshop at the University of Murcia, especially Antonio Juan García Fernández, Emma Martínez López, Jose Francisco Calvo Sendin, Jose Enrique Martínez, Pilar Gómez Ramírez and Silvia Espin. The study would not have been possible to conduct without data provided by EURAPMON's National Coordinators, and we would like to thank them for their collaboration and support: Aleksandre Abuladze (Georgia), Alessandro Andreotti (Italy), Arianna Aradis (Italy), János Bagyura (Hungary), Dimitris E. Bakaloudis (Greece), Václav Beran (Czech Republic), Edward Bonavia (Malta), Szilard Daroczi (Romania), Andy Dobson (Great Britain), Valery Dombrovski (Belarus), Miroslav Dravecký (Slovakia), Vlatka Dumbović Mazal (Croatia), Vladimir Galushin
(Russia), Anita Gamauf (Austria), Zuzana Guziová (Slovakia), Ena Hatibović (Bosnia \& Herzegovina), Björn Helander (Sweden), Peter Hellström (Sweden), Márton Horváth (Hungary), Dražen Kotrošan (Bosnia \& Herzegovina), Ubbo Mammen (Germany), Allan Mee (Ireland), Krešimir Mikulić (Croatia), Rein Nellis (Estonia), Torgeir Nygård (Norway), Luís Palma (Portugal), Jean-Yves Paquet (Belgium), Jānis Reihmanis (Latvia), José Antonio Sánchez Zapata (Spain), Janusz Sielicki (Poland), Svetoslav Spasov (Bulgaria), Jean-Paul Urcun (France), and Glenn Vermeersch (Belgium). For help in preparation of the map we would like to thank Andrej Kapla (National Institute of Biology, Slovenia). IB was supported partly by an NGO operating grant from the European Commission (DG Environment, under the LIFE+ programme) to Stichting BirdLife Europe.

\section{Povzetek}

Kljub temu da so ptice roparice, ujede Falconiformes in sove Strigiformes, prepoznane kot ključne vrste $\mathrm{v}$ ekosistemih in so zelo občutljive za okoljske spremembe, v Evropi še ni mednarodnega usklajenega monitoringa teh vrst. Zato so pri Evropski znanstveni fundaciji zagnali projekt EURAPMON, katerega cilj je vzpostavitev trajne panevropske raziskovalne mreže na področju monitoringa ujed in sov v Evropi. Pregled obstoječih shem monitoringa v 28 evropskih državah, ki so jih na EURAPMON-ovi delavnici v Murciji (Španija) leta 2012 predstavili nacionalni koordinatorji, je pokazal, da je $\mathrm{v}$ trenutne sheme monitoringov vključenih malo vrst (predvsem ujede in nekatere redke vrste). Največ shem monitoringa je vzpostavljenih za spremljanje populacije planinskega orla Aquila chrysaetos med ujedami in za veliko uharico Bubo bubo med sovami, dobra pokritost območja razširjenosti $\mathrm{z}$ monitoringom pa je dosežena le pri nekaterih ozko razširjenih vrstah. Ohranjanje ugodnega stanja populacij je glavni razlog za monitoring, ki ga večinoma opravljajo nevladne organizacije, končni uporabniki rezultatov monitoringa pa so večinoma vladne ustanove. Mednarodno sodelovanje na področju monitoringa ujed in sov je večinoma regionalno omejeno $\mathrm{z}$ malo panevropskimi povezavami. Kot pozitivne lastnosti obstoječih monitoringov so nacionalni koordinatorji označili vključevanje prostovoljcev; kot pomanjkljivosti pa pomanjkanje delovne sile (majhno število prostovoljcev) ter osredotočanje na redke vrste. Med prioritetami za razvoj shem monitoringa v prihodnosti so: izboljšanje nacionalne koordinacije, podpora za večje vključevanje prostovoljcev ter 
zagotavljanje stabilnega financiranja. Prihodnja analiza EURAPMON-ovih vprašalnikov o obstoječih shemah monitoringa bo pokazala pomanjkljivosti $\mathrm{v}$ znanju in pripravila priporočila za metodologije. Tak prenos dobrih praks so nacionalni koordinatorji označili kot ključni rezultat mednarodnega sodelovanja.

\section{References}

BirdLife International (2004): Birds in Europe: population estimates, trends and conservation status. BirdLife Conservation Series No. 12. - BirdLife International, Cambridge.

Burfield, I. (2008): The Conservation Status and Trends of Raptors and Owls in Europe. - Ambio 37 (6): 401-407.

Carothers, J.H. \& Jaksic, F.M. (i984): Time as a niche difference: the role of interspecific competition. - Oikos 42: 403-406.

DukE, G. (2008): The EU environmental policy context for monitoring for and with raptors in Europe. - Ambio 37 (6): 397-400.

EURAPMON (20I2): Research and Monitoring for and with Raptors in Europe. Brochure. - European Science Foundation, Strasbourg Cedex. (available at http://www. eurapmon.net)

EURAPMON (2013): Workshop - inventory of existing raptor monitoring in Europe. Final Report to ESF. (available at http://www.eurapmon.net/sites/default/ files/pdf-s/eurapmon_workshop_murcia_report_final. pdf)

Gómez-Ramírez, P., Shore, R.F., van den Brink, N.W., van Hattum, B., Bustnes, J.O., Duke, G., Fritsch, C., García-Fernández, A.J., Helander, B.O., Jaspers, V., Krone, O., Martínez-López, E., Mateo, R., Movalli, P. \& Sonne, C. (submitted): The first inventory of existing raptor contaminant monitoring activities in Europe. - Environment International.

Hardey, J., Crick, H., Wernham, C., Riley, H., Etheridge, B. \& Thompson, D. (2009): Raptors, a Field Guide for Surveys and Monitoring. Second Edition. The Stationery Office, Edinburgh.

Hartert, E. (I92i): Birds of Palearctic Fauna. Part II. Verlag von R. Friedländer \& Sohn, London.

Helander, B., Bignert, A. \& Asplund, L. (2008): Using Raptors as Environmental Sentinels: Monitoring the White-tailed Sea Eagle Haliaeetus albicilla in Sweden. Ambio 37 (6): 425-431.

Kotrošan, D. \& Hatibović E. (20I2): Raptors in Bosnia and Herzegovina - status and perspectives for monitoring development. - Acrocephalus 33 (154/155): 173-179.

Kovács, A., Mammen, U. \& Wernham, C. (2008): European monitoring for Raptors and Owls: State of the Art and Future Needs. - Ambio 37 (6): 401-409.

Linnaeus, C. (1758): [Systema Naturae. Tomus I. Editio decima, reformata.] - Impensis Driect. Laurentii Salvii, Holmiae. (in Latin)

MiккоLa H. (I983): Owls of Europe. - T \& A D Poyser, London.

Movalli, P., Duke, G. \& Osborn, D. (2008): Introduction to monitoring for and with raptors. - Ambio 37 (6):
395-396.

PECBMS (2009): The State of Europe's Common Birds 2008. - CSO/RSPB, Prague.

Rоот, R. (1967): The niche exploitation pattern of the blue-grey gnatcatcher. - Ecological Monographs 37 (3): 317-350.

Ružić, M., Radaković, M., Veselinović, D., Rudić, B., Kulić, S., Vučićević, I., Demajo, M., Nagulov, S., Golubović, A. \& Miljković, N. (2010): [Long-eared Owl Asio otus winter roosts in Central Serbia 20062011: distribution, numbers and roost site preferences.] - Ciconia 19: 97-109. (in Serbian, English summary)

Saurola, P. (2008): Monitoring birds of prey in Finland: a summary of methods, trends and statistical power. Ambio 37 (6): 413-419.

Sergio, F. \& Hiraldo, F. (2008): Intraguild predation in raptor assemblages: a review. - Ibis 150, Suppl. 1: 132145.

Sergio, F., Marchesi, L. \& Pedrini, P. (2003): Spatial refugia and the coexistence of a diurnal raptor with its intraguild owl predator. - Journal of Animal Ecology 72 (2): $232-245$.

Sergio, F., Newton, I. \& Marchesi, L. (2005): Top predators and biodiversity. - Nature 436: 192.

VRezec, A. \& Tome, D. (2004): Altitudinal segregation between Ural Owl Strix uralensis and Tawny Owl $S$. aluco: evidence for competitive exclusion in raptorial birds. - Bird Study 51 (3): 264-269.

Arrived / Prispelo: 14. 6. 2013

Accepted / Sprejeto: 1.7. 2013 